\title{
Nickel (II) and Cobalt (II) Complexes of Some Amino Acid-based Surfactants with Antimicrobial Activity
}

\begin{abstract}
DANA VARASTEANU, IRINA CHICAN*, SANDA MARIA DONCEA, IULIANA RAUT, MARIANA CALIN, LUIZA JECU
National Research \& Development Institute for Chemistry and Petrochemistry ICECHIM-Bucharest, 202 Splaiul Independentei, postal code 060021, Romania

Nickel and cobalt complexes of lauroyl-glycine, lauroyl-glycylglycine and 1,12-dodecandioyl-diglycylglycine were synthesized. The FTIR spectroscopy confirmed the complex formation. The antimicrobial activity of synthesized nickel and cobalt complexes was investigated against several bacteria and fungi: Bacillus cereus, Pseudomonas aeruginosa, Candida albicans, and Aspergillus flavus. Generally, the nickel and cobalt complexes of the investigated surfactants showed no antimicrobial activity on Pseudomonas aeruginosa, a moderate one on Bacillus cereus and Aspergillus flavus. The most susceptible microorganism was Candida albicans, which is considered one of most common nosocomial infections. The results suggest the potential application of tested compounds as antimicrobial agents against targeted pathogens.
\end{abstract}

Keywords: amino acid-based surfactants, metal complex, antimicrobial activity

Metal and metal complex combinations with different ligands are of particular importance in medicine due to their anti-arthritic, antibacterial, antitumor, antidepressant and antihypertensive properties. Antimicrobial activity of complex combinations is explained by the theory of chelation. By forming chelates, the metal ion orbits overlap with the orbital atoms of the donor groups. As a result, delocalisation of $\succsim$ electrons increases in the chelated ring, which increases the lipophilic character of the metal chelate and favours its penetration through the lipid membrane of the bacteria. At the same time, the binding sites of biologically active metals with the proteins of the microorganisms are blocked, thus reducing their structural stability. Metal complexes also cause changes in cellular respiration, blocking protein synthesis, thus preventing the development of microorganisms. Antimicrobial activity is influenced by the nature of the donor molecules in the ligand molecule but also by the nature of the metal ion in the complex combination [1]. The involvement of coordination compounds in these phenomena is determined by the possibility of interacting with microorganisms (bacteria and fungi) that cause it various infectious diseases. Metal ions can coordinate on some parts of the microorganism or complex combination can be accomplished via the ligand interactions through hydrogen bonds or weak physical links that can cause alterations that lead to the reduction or elimination of their ability to cause the disease.

Since Rosenberg's discovery of cisplatin (cisdiaminodichloroplatin (II)) an effective inorganic product in the treatment of various cancers, many products have been developed both in the field of anti-tumor products and those with antimicrobial properties [2,3]. Products with antimicrobial properties have emerged as a necessity for the increased resistance of pathogenic microorganisms to current antibiotics. Transition metal complexes with various Schiff base derivatives have been studied for their antimicrobial and chemotherapeutic activity. Various studies show that the azomethine group $>\mathrm{C}=\mathrm{N}$ - has a significantbiological significance in obtaining these effects, but antimicrobial and chemotherapeutic activity may increase several times by complexation with metal ions [4-7].

Transition metal complexes ( $\mathrm{Co}, \mathrm{Cu}, \mathrm{Ni}$ and $\mathrm{Zn}$ ) with condensation products of diketones with amino acids [8], or with different amino acids: methionine, phenylalanine, valine, leucine, lysine, glycine [9-14 ] show antibacterial and antifungal activity tested against pathogenic strains such as Bacillus subtilis, Bacillus cereus, Staphylococcus aureus, Escherichia coli, Shigella, Pseudomonas aeruginosa, Salmonella typhi, Micrococcus luteus, Trichophyton logifusus, Candida albicans, Aspergillus flavus, Fusarium solani .

The analysis of literature data has highlighted the fact that transition metal complexes of acylated amino acids were not used as antimicrobial agents, therefore we synthesized and characterized $\mathrm{Ni}$ and Co complexes of lauroyl-glycine, lauroyl-glycylglycine and 1,12dodecandioyl-diglycylglycine and evaluated their antimicrobial activity against Bacillus cereus, Pseudomonas aeruginosa, Candida albicans and Aspergillus flavus strains.

The selection criterion for these strains was their pathogenic potential. Pseudomonas aeruginosa is a Gramnegative bacterium producing infections at humans, animals and plants. The strain causes nosocomial infections in immunocompromised individuals; this species infects the lung, urinary tract, burns and wounds. Biofilms of $P$. aeruginosa can cause bacteraemia in immunocompromised and elderly people. Because it can cause nosocomial infections, it is considered a model body for the study of antibiotic-resistant bacteria [15]. Bacillus cereus is a strain of beta haemolytic Gram-positive bacterium. It is involved in a diarrhoeal type of food poisoning, caused by complex enterotoxins produced during vegetative grow th of $B$. cereusin the small intestine [16]. Candida albicans is a species of yeast fungus that can grow in leaved and filamentous form, producing a series of infections. Itcan also produce systemic infections (fungi) in immunocompromised patients and may cause death [17]. It can form biofilms on the surface of medical instruments [18]. Aspergillus flavus is a species of filamentous fungus that is found in the environment and can be pathogenic to humans, being associated with lung aspergillosis [19] and sometimes with corneal, ear, and nasoorbital infections. Spores of this species are allergens. Many strains produce aflatoxin and toxic and carcinogenic compounds. 


\section{Experimental}

\section{Synthesis of surfactants}

In order to obtain products with antimicrobial properties, amino acid-based surfactants, namely lauroyl-glycine (LG), lauroyl-glycylglycine (LGG) and 1,12-dodecandioyldiglycylglycine (L2GG), have been synthesized and characterized. The amino-acid based surfactants were synthesized according to Schotten-Baumann method. The synthesis of amino acid-based surfactants was described elsewhere [20,21]. Products were neutralised with $25 \%$ $\mathrm{NaOH}$ solution in order to be in the deprotonated state, necessary in complexation step.

\section{Synthesis of complexes}

The synthesis of cobalt (II) and nickel (II) complexes of lauroyl-glycylglycine was described in a previous work [22]. Accordingly, for the synthesis of cobalt (II) and nickel (II) complexes of lauroyl-glycine and 1,12-dodecandioyldiglycylglycine the same procedure was followed.

For the synthesis of lauroyl-glycine complexes with $\mathrm{Ni}$ and $\mathrm{C} 0,0.02$ mole of sodium lauroyl glycinate were dissolved in $10 \mathrm{~mL}$ distilled water. To this solution was graduallyadded under stirring 0.01 moles of cobaltchloride, respectively nickel acetate tetrahydrate, dissolved in 10 $\mathrm{mL}$ of distilled water. The formed mixture was kept for 10 minutes under stirring at room temperature. The formed complexes were filtered off, washed with distilled water and dried in air at room temperature.

For the synthesis of 1,12-dodecandioyl-diglycylglycine complexes with $\mathrm{Ni}$ and $\mathrm{Co}, 0.01$ mole of 1,12-dodecandioyldiglycylglycine disodium salt were dissolved in $25 \mathrm{~mL}$ distilled water. To this solution was gradually added under stirring 0.01 moles of cobalt chloride, respectively nickel acetate tetrahydrate, dissolved in $10 \mathrm{~mL}$ of distilled water. The formed mixture was kept for 10 min under stirring at room temperature. The formed complexes were filtered off, washed with distilled water and dried in air at room temperature.

\section{Infrared spectroscopy}

Fourier transform infrared spectroscopy (FTIR) spectra were registered with a Spectrum GX, Perkin Elmer instrument by transmission technique, in $\mathrm{KBr}$ pellet, for lauroyl-glycine, 1,12-dodecandioyl-diglycylglycine and the corresponding $\mathrm{Co}$ and $\mathrm{Ni}$ complexes. The lauroylglycylglycine and corresponding complexes were discussed elsewhere [22].

\section{Antimicrobial activity}

Antimicrobial activity of complexes was performed using the disc diffusion method. As culture media were used simple agar and solid Sabouraud medium, with following composition ( $\mathrm{g} / \mathrm{L})$ : peptone, $10 \mathrm{~g}$; $\mathrm{D}+$ glucose, $40 \mathrm{~g}$; agar, $15 \mathrm{~g}$; distilled water, $1000 \mathrm{~mL}$. Strains of Bacillus cereus, Pseudomonas aeruginosa, Candida albicans and Aspergillus flavus are from the Microbial Collection of the Biotechnology Department of ICECHIM. Solutions of $10^{-2} \mathrm{~mol} / \mathrm{L} \mathrm{si} 10^{-3} \mathrm{~mol} / \mathrm{L}$ were made from $\mathrm{Ni}$ and Co complexes of lauroyl-glycine, lauroyl-glycylglycine and 1,12-dodecandioyl-diglycylglycine. The solubilising agent was isopropyl alcohol for lauroyl-glycine complexes and distilled water for lauroyl-glycylglycine and 1,12dodecandioyl-diglycylglycine complexes.

\section{Results and discussions}

Amino acid-based surfactants are a relatively new class of ecological, biocompatible and biodegradable surfactants. Due to their safety profile, amino acid-based surfactants are recommended for biomedical applications.
The variety of amino acids allows the synthesis of surfactants with tailored properties for specific biomedical applications. The surface active properties and selfassembly capacity are influenced by the nature of amino acid residue and the chirality. Cationic amino acid surfactants are known to have antimicrobial properties [ 23 , 24], while anionic amino acid ( $\mathrm{N}$-acyl derivatives) do not show antimicrobial properties.

Taking into consideration that transition metal complexes with different ligands possess antimicrobial activities, the aim of this work was to study the antimicrobial activity of $\mathrm{Co}$ and Ni complexes of glycinebased N-acylated surfactants.

Solubilisation of complexes of amino acid-based surfactants in distilled water can lead to colloidal dispersions. This is the case of $\mathrm{Co}$ and $\mathrm{Ni}$ complexes of lauroyl-glycylglycine, which forms colloidal dispersions in aqueous medium at $10^{-2} \mathrm{~mol} / \mathrm{L}$ concentration. By diluting the complexes at $10^{-3} \mathrm{~mol} / \mathrm{L}$ concentration the interaction between the molecules decreases, causing a decrease in viscosity. $\mathrm{Co}$ and $\mathrm{Ni}$ complexes of 1,12-dodecandioyldiglycylglycine are more soluble in water, since bolaamphiphilic structure has two hydrophilic head groups, thus having a higher lipophilic-hidrophilic balance value. Co and $\mathrm{Ni}$ complexes of lauroyl-glycine are insoluble in water, but soluble in isopropyl alcohol. The complexes showed the characteristic colors, pink for Co complexes and pale green for Ni complexes, being in agreement with those obtained for similar coordination compounds.

FTIR spectra confirmed the complex formation. For Co and $\mathrm{Ni}$ complexes of lauroyl-glycylglycine FTIR spectra were analyzed in a previous work [22].

FTIR spectra of Co and Ni complexes of lauroyl-glycine and 1,12-dodecandioyl-diglycylglycine also confirmed the complex formation (fig. 1 and 2).

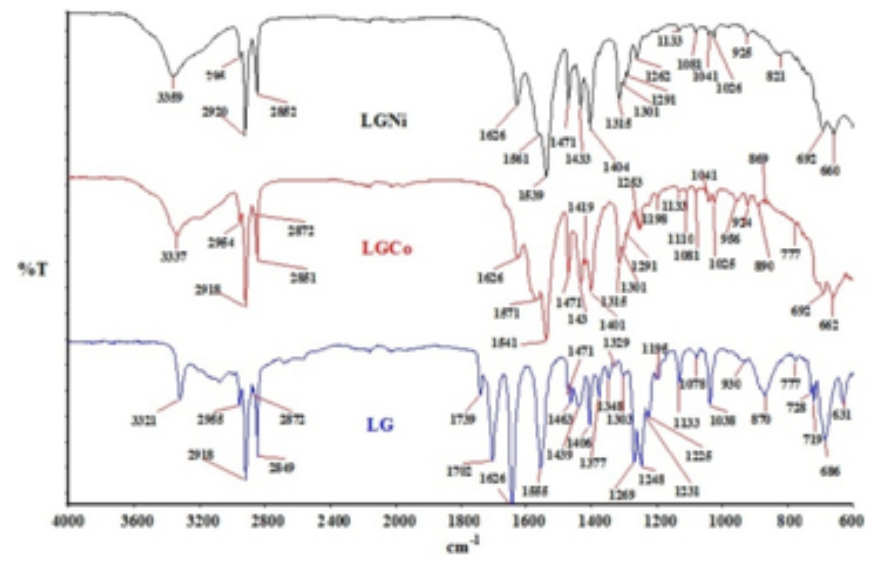

Fig. 1. FTIR spectra of lauroyl-glycine and its $\mathrm{Co}$ and Ni complexes

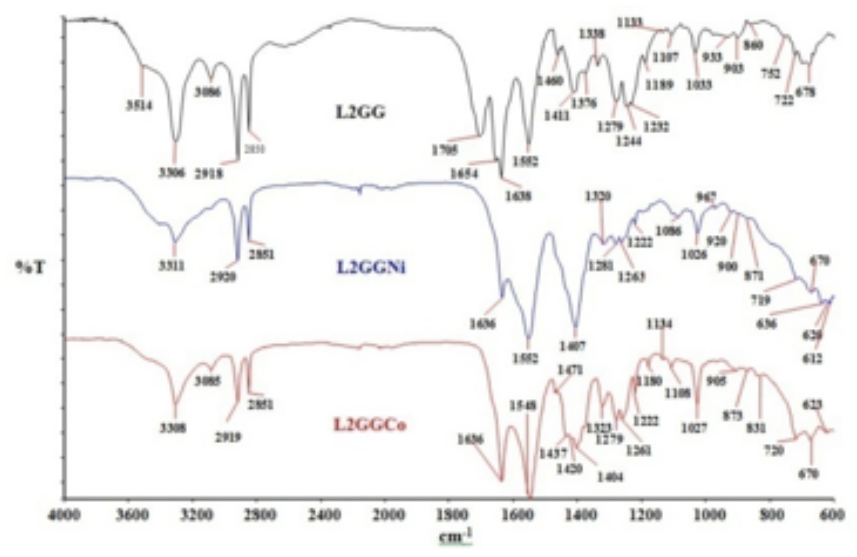

Fig. 2. FTIR spectra of 1,12-dodecanedioyl-diglycylglycine and its $\mathrm{Co}$ and Ni complexes 
The complexation reaction of $L G$ is demonstrated by the disappearance of the band from $1739 \mathrm{~cm}^{-1}$ specific for the $\mathrm{C}=0$ group and from $1702 \mathrm{~cm}^{-1}$ specific for the COOgroup, by the vibrational attenuation for the $-\mathrm{CH}_{2}$ chain groups and by shifted bands for $\mathrm{CONH}$ Amide I, for $\mathrm{CONH}$ Amide II and $\mathrm{CH}$ Amide III, as well as for $\mathrm{C}-\mathrm{N}$ and $\mathrm{C}-\mathrm{C}$ bands.

The difference between the $\mathrm{Ni}$ and $\mathrm{Co}$ complexes is well emphasized not only by the different colours of the two products but also by the FTIR spectra of the vibration bands and / or the appearance of new bands. The specific bands for the Ni complex are: $-\mathrm{NH}$ and / $\mathrm{Or}-\mathrm{OH}$ with Ni at $3359 \mathrm{~cm}^{-1}$, CONH Amide II with Ni at $1561 \mathrm{~cm}^{-1}$ and C-C with $\mathrm{Ni}$ at $821 \mathrm{~cm}^{-1}$. The specific bands for the Co complex are: - $\mathrm{NH}$ and / or $-\mathrm{OH}$ with Co at $3337 \mathrm{~cm}^{-1}$, CONH Amide II with $\mathrm{Co}$ at $1571 \mathrm{~cm}^{-1},-\mathrm{CH}$ and / or N-H Amide III with Co at $1253 \mathrm{~cm}^{-1},-\mathrm{CH}_{2},-\mathrm{CH}_{3}$ with $\mathrm{Co}$ at $1225 \mathrm{~cm}^{-1}$ and C-N with $\mathrm{Co}$ at $956 \mathrm{~cm}^{-1}$. These absorption bands differentiate the two synthesized complexes.

The chemical structure of 1,12-dodecanedioyl diglycylglycine, synthesized from dodecanedioyl dichloride on which two dipeptide molecules are grafted, is similar to lauroyl glycine, both of which are amphoteric substances. Therefore, it can be concluded that the dodecanedioyldiglycylglycine vibrational bands are of the same nature as those of the lauroyl-glycine.

The fact that the complexation reaction took place is highlighted by the disappearance of the $1705 \mathrm{~cm}^{-1}$ band, specific for $\mathrm{COO}$ - group, the attenuation of the vibrations for the $-\mathrm{CH}_{2}$ chain groups and the shifted for the $\mathrm{CONH}$ Amide I, CONH Amide II and CH Amide III bands, and for $\mathrm{CN}$ and $\mathrm{CC}$ bands.

The difference between the $\mathrm{Ni}$ and $\mathrm{Co}$ complexes is well emphasized not only by the different colours of the two products but also by the FTIR spectra of the vibrational bands and / or the appearance of new bands. The specific bands for the Ni complex are: - $\mathrm{NH}$ and / or $-\mathrm{OH}$ with Ni at $3406 \mathrm{~cm}^{-1}$, CONH Amide II with Ni at $1552 \mathrm{~cm}^{-1},-\mathrm{CH}_{2}$ and I or -COC- with Ni at $1194 \mathrm{~cm}^{-1}$ respectively at $1086^{2} \mathrm{~cm}^{-1}$ and $\mathrm{C}-\mathrm{C}$ with Ni at $923 \mathrm{~cm}^{-1}$, at $794 \mathrm{~cm}^{-1}$ and at $636 \mathrm{~cm}^{-1}$. The specific bands for the Co complex are: -NH and / or $\mathrm{OH}$ with $\mathrm{Co}$ at $3308 \mathrm{~cm}^{-1}$, CONH Amide II with Co at 1548 $\mathrm{Cm}^{-1},-\mathrm{CH}_{2^{\prime}}-\mathrm{CH}_{3}$ with $\mathrm{Co}$ at $1471 \mathrm{~cm}^{-1}$, at $1437 \mathrm{~cm}^{-1}$ and at $1420 \mathrm{~cm}^{-1^{2}}, \mathrm{CH}_{3}$ and / or -COC- with Co at $1134 \mathrm{~cm}^{-1}$, and C$C$ with $\mathrm{Co}$ at $840 \mathrm{~cm}^{-1}$ and at $831 \mathrm{~cm}^{-1}$. These absorption bands differentiate the two synthesized complexes.

Interpretation of the criteria for the diameter of inhibition zone is performed in accordance with the Performance standards for antimicrobial disk susceptibility tests; approved standard- ed. 11th; J anuary 2012, M02-A11, vol. 32, no. 1, (Replaces M02-A10 Vol. 29 No. 1): diameter of inhibition zone $\geq 20 \mathrm{~mm}$ - susceptible; $15-19 \mathrm{~mm}$ intermediate; $\leq 14 \mathrm{~mm}$ - resistant.

Antimicrobial activity was assessed by measuring the inhibition zone of the test microorganism. The results are presented in the tables 1,2 and 3.

Evaluation of the antimicrobial activity of lauroyl-glycine cobalt and nickel complexes (table 1) led to the following conclusions:

- The bacterial strain of Pseudomonas aeruginosa was not sensitive at the action of tested complexes. Gramnegative bacteria, such as Pseudomonas aeruginosa, possess an outer membrane with polysaccharide structure, acting as a barrier against antibiotics [ $9,25,26]$;

- In the case of testing the activity of the compounds on the Bacillus cereus strain, high values of the diameter of the inhibition zone of $20 \mathrm{~mm}$ were obtained only for the cobalt complex at the concentration of $10^{-2} \mathrm{~mol} / \mathrm{L}$, double than the value recorded for the nickel compound at the same concentration. For the more diluted sample from

\begin{tabular}{|c|c|c|c|c|}
\hline $\begin{array}{c}\text { Complex/ } \\
\text { Conc., mol/L }\end{array}$ & \multicolumn{5}{|c|}{ Diameter of inhibition zone, mm } \\
\cline { 2 - 5 } & $\begin{array}{c}\text { Pseudomonas } \\
\text { aeruginosa }\end{array}$ & $\begin{array}{l}\text { Bacillus } \\
\text { cereus }\end{array}$ & $\begin{array}{l}\text { Candida } \\
\text { albicans }\end{array}$ & $\begin{array}{l}\text { Aspergillus } \\
\text { flavus }\end{array}$ \\
\hline $\begin{array}{c}\text { LGNi } \\
10^{-2}\end{array}$ & 0 & 10 & 23 & 21 \\
\hline $\begin{array}{c}\text { LGNi } \\
10^{-3}\end{array}$ & 0 & 10 & 22 & 10 \\
\hline $\begin{array}{c}\text { LGCo } \\
10^{-2}\end{array}$ & 0 & 20 & 28 & 15 \\
\hline $\begin{array}{c}\text { LGCo } \\
10^{-3}\end{array}$ & 0 & 10 & 25 & 8 \\
\hline
\end{tabular}

\begin{tabular}{|c|c|c|c|c|}
\hline \multirow{2}{*}{$\begin{array}{c}\text { Complex } \\
\text { Conc., mol/L }\end{array}$} & \multicolumn{4}{|c|}{ Diameter of inhibition zone, mm } \\
\cline { 2 - 5 } & $\begin{array}{c}\text { Pseudomonas } \\
\text { aeruginosa }\end{array}$ & Bacillus cereus & $\begin{array}{l}\text { Candida } \\
\text { albicans }\end{array}$ & $\begin{array}{l}\text { Aspergillus } \\
\text { flavus }\end{array}$ \\
\hline $\begin{array}{c}\text { LGGNi } \\
10^{-2}\end{array}$ & 8 & 8 & 10 & 0 \\
\hline $\begin{array}{c}\text { LGGNi } \\
10^{-3}\end{array}$ & 0 & 10 & 0 & 0 \\
\hline $\begin{array}{c}\text { LGGCo } \\
10^{-2}\end{array}$ & 8 & 9 & 9 & 0 \\
\hline $\begin{array}{c}\text { LGGCo } \\
10^{-3}\end{array}$ & 0 & 11 & 0 & 0 \\
\hline
\end{tabular}

Table1
INHIBITION OF PATHOGENS GROWTH BY CO AND Ni COMPLEXES OF LAUROYL-GLYCINE

\begin{tabular}{|c|c|c|c|c|}
\hline $\begin{array}{c}\text { Complex } \\
\text { Conc., moll }\end{array}$ & \multicolumn{4}{|c|}{ Diameter of inhibition zone, mm } \\
\cline { 2 - 5 } & $\begin{array}{c}\text { Pseudomonas } \\
\text { aeruginosa }\end{array}$ & Bacillus cereus & $\begin{array}{l}\text { Candida } \\
\text { albicans }\end{array}$ & $\begin{array}{l}\text { Aspergillus } \\
\text { flavus }\end{array}$ \\
\hline $\begin{array}{c}\text { L2GGNi } \\
10^{-2}\end{array}$ & 0 & 14 & 21 & 12 \\
\hline $\begin{array}{c}\text { L2GGNi } \\
10^{-3}\end{array}$ & 0 & 0 & 0 & 0 \\
\hline $\begin{array}{c}\text { L2GGCo } \\
10^{-2}\end{array}$ & 0 & 17 & 24 & 13 \\
\hline $\begin{array}{c}\text { L2GGCo } \\
10^{-3}\end{array}$ & 0 & 0 & 0 & 0 \\
\hline
\end{tabular}

Table 2

INHIBITION OF PATHOGENS GROWTH BY CO AND Ni COMPLEXES OF LAUROYL-GLYCYLGLYCINE

Table 3

INHIBITION OF PATHOGENS GROWTH BY CO AND Ni COMPLEXES

OF 1,12-DODECANDIOYL-DIGLYCYLGLYCINE 
both compounds, the inhibition zone values were similar, $10 \mathrm{~mm}$. The moderate antibacterial activity of the tested compounds is not unexpected, as this bacterium forms spores very resistant to environmental conditions [9].

-The two metallic compounds were very active against Candida albicans, for which the diameter of the inhibition zone reached high values for both concentrations.

- Aspergillus flavus exhibited a relatively higher sensitivity for the nickel compound at $10^{-2} \mathrm{~mol} / \mathrm{L}$ concentration, for which an inhibition area of $21 \mathrm{~mm}$ diameter was recorded, compared to the $15 \mathrm{~mm}$ diameter obtained with the cobalt compound at the same concentration.

As shown in table 2, LGGMe did not show antimicrobial activity against Aspergillus flavus fungus strain. In case of activity against the Bacillus cereus strain of the cobalt complex there were higher inhibition diameters at lower dilution, which can be explained by a better diffusion in the culture medium of the more dilute metal complex.

The tested metal complexes did not exhibit antibacterial activity against the $P$. aeruginosa strain (table 3). The most significant inhibition of the $B$. cereus strain exerted by the Nickel complex was obtained for $10^{-2} \mathrm{~mol} /$ $L$ concentration, with a diameter of inhibition zone of 14 $\mathrm{mm}$. At $C$. albicans, the higher inhibition of $21 \mathrm{~mm}$ was reached for the same concentration of complex. As regarding the activity of the cobalt compounds against $B$. cereus, the best inhibition of the microorganism was obtained in the case of L2GGNi $10^{-2} \mathrm{~mol} / \mathrm{L}$, where the inhibition diameter were was $17 \mathrm{~mm}$. In the case of cobalt activity against the $C$. albicans strain, the best inhibition of $24 \mathrm{~mm}$ diameter was found for the same complex. $A$. niger strain was inhibited by $\mathrm{Co}$ and Ni complexes of 1,12dodecandioyl-diglycylglycine, where the inhibition diameter were 13 and $12 \mathrm{~mm}$, respectively.

\section{Conclusions}

$\mathrm{Ni}$ and Co complexes of some amino acid-based surfactants, namely lauroyl-glycine, lauroyl-glycylglycine and 1,12-dodecandioyl-diglycylglycine were synthesized and the FTIR spectra confirmed by structural evidence the complex formation.

The tested metal complexes did not exhibit antibacterial activity against the $P$. aeruginosa strain. In Gram-negative bacteria the presence of additional structures made up of polysaccharides protects the cell membrane from toxic molecules. Also, these types of bacteria produce extracellular polymeric compounds that reduce permeability of the cell membrane. In addition, electrostatic interactions between the bacterial cell and the tested metal compounds are poorer in Gram-negative bacteria compared to Gram-positive. In the case of testing the activity of the compounds on the Bacillus cereusstrain, the studied complexes showed moderate activity, high values of the diameter of the inhibition zone of $20 \mathrm{~mm}$ were obtained only for the cobalt complex LGCo at the concentration of $10^{-2} \mathrm{~mol} / \mathrm{L}$. The synthesized complexes at the concentration of $10^{-2} \mathrm{~mol} / \mathrm{L}$ were active especially against $C$. albicans and exhibited a moderate activity against $A$. flavus.

Synthesis, characterisation and evaluation of antimicrobial activity of cobalt and nickel complexes of lauroyl-glycine, lauroyl-glycylglycine and 1,12-dodecandioyl-diglycylglycine aimed to diversify the range of antimicrobial products. The results suggest their potential application as antifungal agents.
Acknowledgements: This work was financially supported by National Authority for Scientific Research and Innovation, in the frame of Nucleu Programme-Project PN 16.31.02.03.

\section{References}

1. RIZZOTTO, M., Metal complexes as antimicrobial agents. In: A Search for Antibacterial Agents. InTech, 2012

2. CHANG, E. L., SIMMERS, C., KNIGHT, D. A., Pharmaceuticals, vol. 3, no. 6, 2010, p. 1711-1728

3. SADLER, P. J., GUO, Z., Pure \&Appl. Chem., vol. 70, no. 4, 1998, p. 863-871

4. JOSEYPHUS, R. S., NAIR, M. S., Arabian J. Chem., vol. 3, no. 4, 2010, p. 195-204

5. REISS, A., FLOREA, S., CAPROIU, T., STANICA, N., Turk. J. Chem., vol. 33, no. 6, 2009, p. 775-783

6. CIOLAN, F., PATRON, L., MURESEANU, M., ROTARU, P., GEORGESCU, I., Rev. Chim. (Bucharest), 63, no. 1, 2012, p. 34-39

7. KRIZA, A., IGNAT, I. U., STANICA, N., DRAGHICI, C. O., Rev. Chim. (Bucharest), vol. 62, no. 7, 2011, p. 696-701

8. CHOHAN, Z., ARIF, M., AKHTAR, M. A., SUPURAN, C. T., Bioinorg. Chem. Appl., vol. 2006, 2006, p. 1-13

9. STANILA, A., BRAICU, C., STANILA, S., POP, R. M., Not. Bot. Horti. Agrobo., vol. 39, no. 2, 2011, p. 124-129

10. AL-JEBOORI, F. H. , AL-SHIMIESAWI, T. A. , JASSIM, O. M., J. Chem. Pharm. Res., vol. 5, no. 10, 2013, p. 172-176

11. INDIRA DEVI, G., SMITHA, P., Int. Res. J. Biological Sci, vol. 2, no. 6, 2013, p. 16-21

12. AIYELABOLA, T., OJ O, I., ADEBAJ O, A., OGUNLUSI, G., OYETUNJI, O., AKINKUNMI, E., ADEOYE, A., Adv. Biol. Chem., vol. 2, no. 3, 2012, p. $268-273$

13.SAHA, S., DHANASEKARAN, D., CHANDRALEKA, S., PANNEERSELVAM, A., Adv. Biol. Chem., vol. 4, no. 4, 2010, p. 224-229

14. MARCU, A., STANILA, A., RUSU, D. , RUSU, M. , COZAR, O., DAVID, L., J OAM, vol. 9, no. 3, 2007, p. 741-746

15. YAYAN, J., GHEBREMEDHIN, B., RASCHE, K., PLoS one, vol. 10, no. 10, 2015, e0139836

16. GRANUM, P. E., LUND, T., FEMS microbiology letters, vol. 157, no. 2, 1997, p. 223-228

17. GROHSKOPF, L. A., ANDRIOLE, V. T., YJBM, vol. 69, no. 6, 1996, p. 505-515

18. TSUI, C., KONG, E. F., JABRA-RIZK, M. A., FEMS Pathogens and Disease, vol. 74, no. 4, 2016, ftw 018

19. MAHGOUB, E. S., EL HASSAN, A. M., Thorax, vol. 27, no. 1, 1972, p. 33-37

20. VARASTEANU, D., PISCUREANU, A., CHICAN, I.E., COROBEA, M.C., U.P.B. Sci. Bull., Series B, vol. 73, no. 3, 2011, p. 147-154

21. CHICAN, I.E., VARASTEANU, D.S., OPROIU, L. C., DONCEA, S.M., Proceeding of International Symposium SIMI The Environment and the Industry, 2016, p. 271-278

22. VARASTEANU, D., COROBEA, M.C., GHIUREA, M., POP, S., CHICAN, I., FLOREA, D., PISCUREANU, A., CALINESCU, I., OAM-RC, vol. 7no. 11-12, 2013, p. 991-996

23. PEREZ, L., PINAZO, A., GARCIA, M. T., LOZANO, M., MANRESA, A., ANGELET, M., PILAR VINARDELL, M., MITJANS, M., PONS, R., INFANTE, M. R., Eur. J. Med. Chem., vol. 44, no. 5, 2009, p. 1884-1892

24. *** US Patent US 5780658, (1998)

25. KABBANI, A. T., HAMMUD, H. H., GHANNOUM, A. M., Chem. Pharm. Bull., vol. 55, no. 3, 2007, p. 446-450

26. FAUNDEZ, G., TRONCOSO, M., NAVARRETE, P., FIGUEROA, G., BMC Microbiol., vol. 4, no. 1, 19, (2004)

$\overline{\text { Manuscript received: } 6.07 .2018}$ 